\title{
Impact of land use and land use history on fruits production of Vitellaria paradoxa (Shea tree) according to agroclimatic zones in Mali (West Africa)
}

\author{
Bokary Allaye Kelly*, Mahesh Poudyal², Jean-Marc Bouvet ${ }^{3,4,5}$ \\ 'Institut d'Economie Rurale, Programme Ressources Forestières Centre Régional de la Recherche Agronomique de \\ Sikasso, BP 178 Sikasso, Mali, ${ }^{2}$ Ecosystem Services for Poverty Alleviation (ESPA) Programme, Argyle House, 3 Lady \\ Lawson St., Level D, Edinburgh EH3 9DR, United Kingdom, ${ }^{3}$ Cirad, UMR AGAP, Amélioration Génétique et Adaptation \\ des Plantes Tropicales et Méditerranéennes, Montpellier, France, ${ }^{4} \mathrm{Cirad}$, dispositif de recherche et d'enseignement \\ en Partenariat "Forêt et biodiversité à Madagascar", Antananarivo, Madagascar, ${ }^{5}$ Agap, Univ Montpellier, CIRAD, \\ INRA, Montpellier Sup-Agro, Montpellier, France
}

Received: November 18, 2018 Accepted: January 05, 2019 Published: January 09, 2019

*Corresponding Authors: Bokary Allaye Kelly, Institut d'Economie Rurale, Programme Ressources Forestières Centre Régional de la Recherche Agronomique de Sikasso, BP 178 Sikasso, Mali

Email: bokarykelly@gmail.com KEYWORDS: Agroclimatic zone, fruit production, land management, mali, stand, Vitellaria paradoxa.

\section{INTRODUCTION}

Vitellaria paradoxa (shea tree or karité), a Sapotaceae, is a dominant tree species in many agroforestry parklands in SubSaharan Africa, represented by the sub-species paradoxa in the western part of the distribution area and the sub-species nilotica in the eastern part. This wild tree species is protected and maintained on farmed fields in most of the parklands of Sudanian and Sudano-Guinean zones in West Africa and plays a significant socio-economic role. The pulp of ripen fruits is very nutritious and provides a key dietary supplement to local people, especially at the end of the dry season when the stocks of staple grains are low [1]. The kernel is rich in fat, fatty acids and tocopherols [2-4]. The butter is used in many African kitchens but also in pharmacology, cosmetics, traditional medicine and as Chocolate Butter Equivalent (CBE) in chocolate industry.

Over the past 10 years, demand for shea products has grown in both the European Union (EU) and the United States (US) and the global demand for shea butter is worth about $\$ 10$ billions and is projected to be worth about $\$ 30$ billions by 2020 [5]. Koloche et al. [6] reported that nut exportation increased and was directed to Asian and European countries. The total collectible production of Shea butter in 2015 was 600,000 tons valued at 10.6 billions in 2016 [7].

Copyright: $\odot 2018$ The authors. This article is open access and licensed under the terms of the Creative Commons Attribution License (http://creativecommons.org/licenses/by/4.0/) which permits unrestricted, use, distribution and reproduction in any medium, or format for any purpose, even commercially provided the work is properly cited. Attribution - You must give appropriate credit, provide a link to the license, and indicate if changes were made. 
According to Maranz et al. [3], about $10 \%$ of nut production in the seven countries included in FAOSTAT estimation is exported. According to Collinson and Zewdie-Bosuener [8], $5 \%$ of exported nut go into cosmetics manufacture and the rest (95\%) goes to food industry principally chocolate manufacturing. Statistics reported by Market Research Future [7] indicated that almost half of the Shea production never reaches the international market and is consumed locally and that Nigeria contributes more than $50 \%$ of the global Shea exports followed by Mali, Burkina Faso, Ghana, Côte d'Ivoire, Benin, and Togo.

While the interest for shea products is growing, shea tree populations and shea fruit production are facing several constraints. Declining tree densities in parklands in several agricultural areas of the Sahel has been highlighted by many studies [9-11]. The combination of drought and increasing population pressure (thereby resulting shortened fallows) and also threat by a plant parasite of the genus Tapinanthus are decreasing the shea populations $[12,13]$.

The main constraints encountered with nut production are the remarkable decrease of the production and its huge fluctuation from year to year. Many attempts were made to explain factors underlying this fluctuation. Variations of fruit production are believed to follow cycles of two, three or more years [14-17], but a relationship with climatic parameters has not been clearly identified. Fluctuation may also result from differential success in pollination [18]. Thus, authors have hypothesized many combined biotic and abiotic factors underlying the annual variation of shea trees' fruit production but this process remains still not fully understood.

Hall et al. [19] stated that, where estimates are made for either parameter, circumstantial details concerning the population under consideration are frequently lacking. Nevertheless, a better knowledge of nut production and shea tree productivity are essential for management and domestication strategies [20].

Therefore, this study aims to assess fruit production of shea trees according to agroclimatic zones since few studies have made comparison among populations located at sites characterized by marked environmental differences [21]. This helps understanding how various factors influence phenological pattern like fruit production and the extent of phenological variability as survival strategy in different environments. The specific research questions addressed in this study are: (i) How does shea fruit production vary according to sites (agroclimatic zones) in Mali?; (ii) How does shea fruit production vary according to land use and land use history?; and (iii) What is the magnitude of interannual variation within zones and land use types?

\section{MATERIAL AND METHODS}

\section{Study Sites}

Three sites, Daelan (district of San) at the northern part of the study area, Mperesso (district of Koutiala) at the centre and Nafégué (district of Kadiolo) at the southern part of the study area (Map 1) were selected for this study. These sites are located in three different agroclimatic zones, North Sudanian (site of Daelan), South Sudanian (site of Mperesso) and North Guinean (site of Nafégué). Some characteristics of the agroclimatic zones in Mali are given in table 1 .

Sudanian zones (North and South) are best described as savannah woodlands and rich in woody perennials [22]. The Guinean zone is a mosaic of savannah woodland and open woodland forest; these two formations being regulary exposed

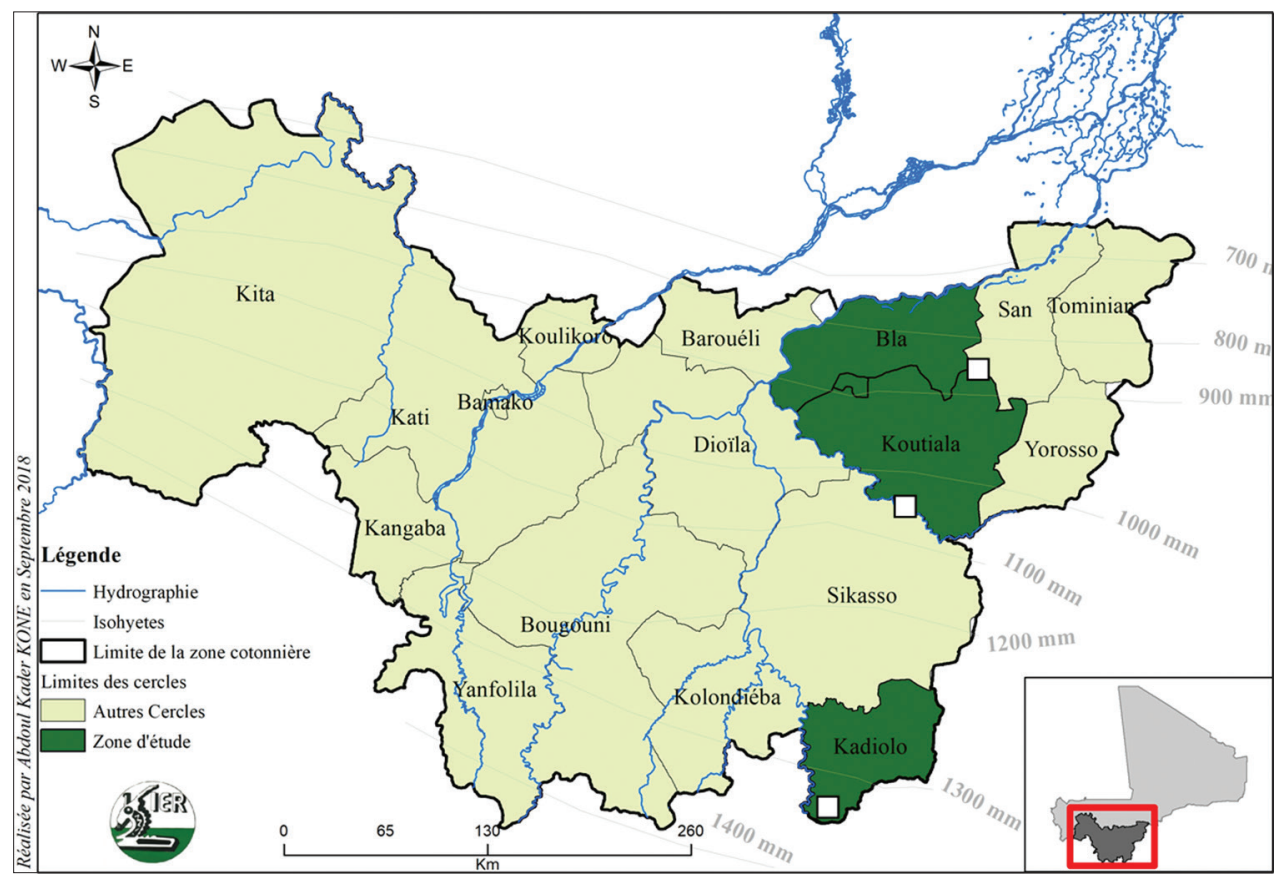

Map 1: Study sites are indicated by white squares: Daelan in the district of San (Ségou region), Mperesso in the district of Koutiala and Nafégué in the district of Kadiolo (Sikasso region) 
Table 1: Agroclimatic zones in Mali

\begin{tabular}{llcc}
\hline Zone & Climate & $\begin{array}{c}\text { Rainfall } \\
\text { mm/year }\end{array}$ & $\begin{array}{c}\text { Length of agr. } \\
\text { Season Days/year }\end{array}$ \\
\hline Saharian & Arid & $<150$ & $<25$ \\
North Sahelian & Semi-arid & $150-350$ & $25-45$ \\
South Sahelian & Semi-arid & $350-550$ & $45-90$ \\
North Sudanian & Semi-humid & $550-750$ & $90-120$ \\
South Sudanian & Semi-humid & $750-1150$ & $120-150$ \\
Guinean & Humid & $1150-1450$ & $150-180$ \\
\hline
\end{tabular}

Republic of Mali (1987, p15); lines in blod indicate the three agroclimatic zones concerned by our study

to bush fires with cereals growing, industrial plants, fruits and tubers [22].

\section{Experimental Design}

In each site, two stands i.e. field and fallow, referde as land use types in this paper were concerned. For each stand, three land use periods (based on the time-lenght the area covered has been under a given land use type) were considered and permanent plots of $50 \mathrm{~m} \times 50 \mathrm{~m}=2500 \mathrm{~m}^{2}(0.25 \mathrm{ha})$ were established for phenology monitoring and fruit production assessment. The land use period was refered as "land use history or land management" in this paper and categorized as follows:

New $(\mathrm{N})$ - the area is under the land use type for $1-5$ years (e.g., field being cultivated for 1-5 years or the land left as fallow for $1-5$ years),

Medium (M) - the area is under the land use type for $6-10$ years,

Old $(\mathrm{O})$ - the area is under the land use type for more than 10 years

Three replicates of each land use history were established for each of the two land use types, giving a total of 18 permanent plots in each site (2 stands $\mathrm{x} 3$ land use history $\mathrm{x} 3$ replicates $=18$ plots).

\section{Sampling Shea Trees}

In each site, 60 trees (10 trees per land use type and land use histories) were selected, measured and monitored for fruit production assessment. Monitored trees were adult shea trees with diameter at breast height $(\mathrm{DBH}) \geq 10 \mathrm{~cm}$, selected on the basis of their fruiting ability observed through phenology monitoring and confirmed by farmers owners of study parcels. The coordinates of each selected shea tree were recorded using GPS and trees were marked with red paint.

\section{Harvesting and Quantification of Production}

Ripe fruits were collected daily from the start (dropping of the first mature fruit) to the end (dropping of the last fruit on the tree) by women from the household owning the land (field/fallow). Collected fruits were gathered separately for each individual tree in bags with label indicating tree identity (number, land use type, land use history). Thereafter, the field technicians pick gathered fruits and proceed to counting and weighing. Data were then recorded on separate sheets for each individual tree. This process was carried out during three years from to 2008 to 2010 .

\section{Recorded Variables}

Morphological traits of shea trees

The monitored adult trees were measured for their morphological traits. Recorded variables were:

- the diameter at breast height (DBH) i.e. the diameter at $1.30 \mathrm{~m}$ above the ground,

- the total height $(\mathrm{H})$,

- the crown diameter in North - South and East - West directions giving by computation the mean crown diameter for each tree (MCD).

\section{Fruit production quantification}

For production quantification, recorded variables were:

- number of harvested fruits per tree,

- weight of harvested fruits per tree in $\mathrm{kg}$.

\section{Data Analysis}

Data were analysed using the sofware SYSTAT 9 For Windows. Descriptive statistics were computed and nested ANOVA (also known as a hierarchical anova; [23]) which takes into account the nested statut of factors was run to test the significance of site, the significance of stand (field, fallow) within site and the significance of land management (new, medium, old) within stand of each site. The fitted model for such analysis was:

$$
\mathrm{y}_{\mathrm{ijk}}=\mu+\tau_{\mathrm{i}}+\beta_{\mathrm{i}(\mathrm{i})}+\gamma_{\mathrm{k}(\mathrm{ii})}+\varepsilon_{1(\mathrm{ijk})}
$$

$\mu=$ overall mean

$\tau i=$ "effect" for ith site

$\beta \mathrm{j}(\mathrm{i})=$ "effect" for $\mathrm{jth}$ stand within ith site

$\gamma \mathrm{k}(\mathrm{ij})=$ "effect" of kth land management for jth stand in ith site

$\varepsilon l(\mathrm{ij} k)=$ random error.

\section{RESULTS}

\section{Morphological Traits of Monitored Individuals}

Results of morphological traits measurements over two years (2007 and 2009) are shown in figure 1 for field stand(Fig.la) and fallow stand (Fig.lb). Site effect was significant for DBH, for $\mathrm{H}$ and for MCD. The site of Nafégué $(\mathrm{Na})$ in the South (ZS) had the lowest mean DBH $(26.05 \mathrm{~cm})$, significantly lower than that of Daelan (Da) in the North (ZN) with $30.71 \mathrm{~cm}$ and that of Mperesso (Mp) in the Centre (ZC) with $31.35 \mathrm{~cm}$. The site of Daelan had the lowest mean H significantly lower than that of Mperesso and that of Nafégué. These last two sites were not significantly different for mean DBH and mean $\mathrm{H}$.

Stand effect within site was significant for DBH but not for $\mathrm{H}$ and for MCD. Fallow stand shown highest mean DBH $(30.46 \mathrm{~cm})$ compared to field stand $(28.27 \mathrm{~cm})$. 
Kelly, et al.

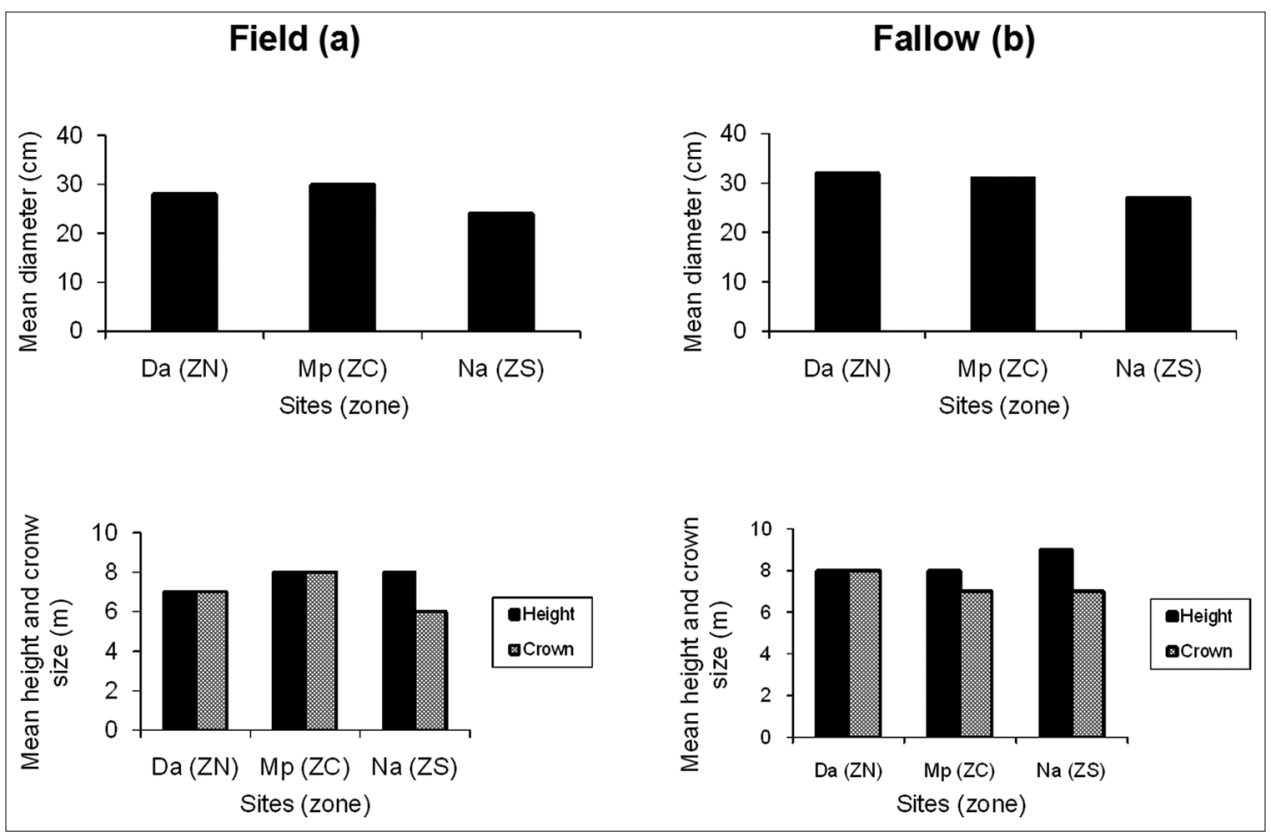

Figure 1: Mean diameter, mean height and mean crown diameter of monitored shea trees per site for each stand

\section{Fruit Production}

Basic statistics of fruit production were shown in table 2.

The nested analysis of variance on fruit yield showed a significant site effect and significant effect of land management within stand. However, the effect of stand within site was not significant (see anova table bellow).

Anova table

\begin{tabular}{lccc}
\hline Source & Df & F-ratio & P \\
\hline Sites & 2 & 6.234 & 0.002 \\
Stands (Sites) & 3 & 0.287 & 0.835 \\
Management (Stands (Sites)) & 12 & 2.046 & 0.020 \\
\hline
\end{tabular}

The site of Mperesso in the south sudanian zone showed the highest fruit mean yield (11 kg/tree), significantly higher than the mean yield observed at Daelan (7 kg/tree) in the north sudanian zone and that observed at Nafégué (6 kg/tree) in the north guinean zone.

The fruit mean yield according to land management within stand in each site was shown in figure 2. In field stand, old fields showed highest means in all sites (Daelan, Fig.2a; Mperesso, Fig.2c and Nafégué, Fig.2e) and in most of cases, new and medium fields showed alsmost similar means. A different pattern was observed for fallow stand. At Daelan (Fig.2b), old fallows showed the highest mean while medium fallows showed the lowest one. At Mperesso (Fig.2d) and at Nafégué (Fig.2f), medium fallows showed highest means and old fallows the lowest ones.

\section{Variation of Fruit Production}

A noticeable variation of fruit yield was observed from year to year for all categories of land management of all stands in all
Table 2: Statistics on the number and fruit yield

\begin{tabular}{lcc}
\hline Statistics & \multicolumn{2}{c}{ Variables } \\
\cline { 2 - 3 } & Number fruits & Fruit yield (kg/tree) \\
\hline Minimum & $0^{\dagger}$ & \\
Maximum & 7694 & 113 \\
Mean & 646 & 7 \\
CV $(\%)$ & 135 & 156 \\
\hline
\end{tabular}

Mean weight of fresh nut was $11.6 \mathrm{~g}$ Mean number of nut in $1 \mathrm{~kg}$ of fresh nuts was 86 nuts

sites (Table 2). The coefficient of variation was also very high (145\%) suggesting huge difference between shea trees regarding fruit production.

\section{DISCUSSION}

Assessment of fruit production of $\mathrm{V}$. paradoxa over 3 years gave a mean number of 646 fruits tree ${ }^{-1}$ over the three sites and a mean yield of $7 \mathrm{~kg}$ tree ${ }^{-1}$ of fresh nuts (Table 2), corresponding to $3.1 \mathrm{~kg}$ tree $^{-1}$ of dry kernel ${ }^{\ddagger}$. This result was closed to that obtained by Boffa et al. [20] for three years study at Thiougou (Burkina Faso). The range of the number of fruits in our study was however wider than that observed by Boffa et al. [20]. Soro et al. [16] found wider range again (0 to 15000 fruits or 0 to $20 \mathrm{~kg}$ of fresh fruits tree $\mathrm{e}^{-1}$ ).

\section{Site Effect on Fruit Production of V. paradoxa}

The nested anova showed significant difference between sites and the site of Mperesso (South Sudanian zone) was better

$\dagger \quad$ Dry kernel represents $69 \%$ of fresh kernel which represents $60 \%$ of fresh nut.

$\$ 2$ shea trees ( $\mathrm{N}^{\circ} 8$ and $\left.\mathrm{N}^{\circ} 15\right)$ in medium fallows at Daelan and 1 shea tree $\left(\mathrm{N}^{\circ} 9\right)$ in old fallows at Mperessso have not fruited during the 3 years of monitoring. 


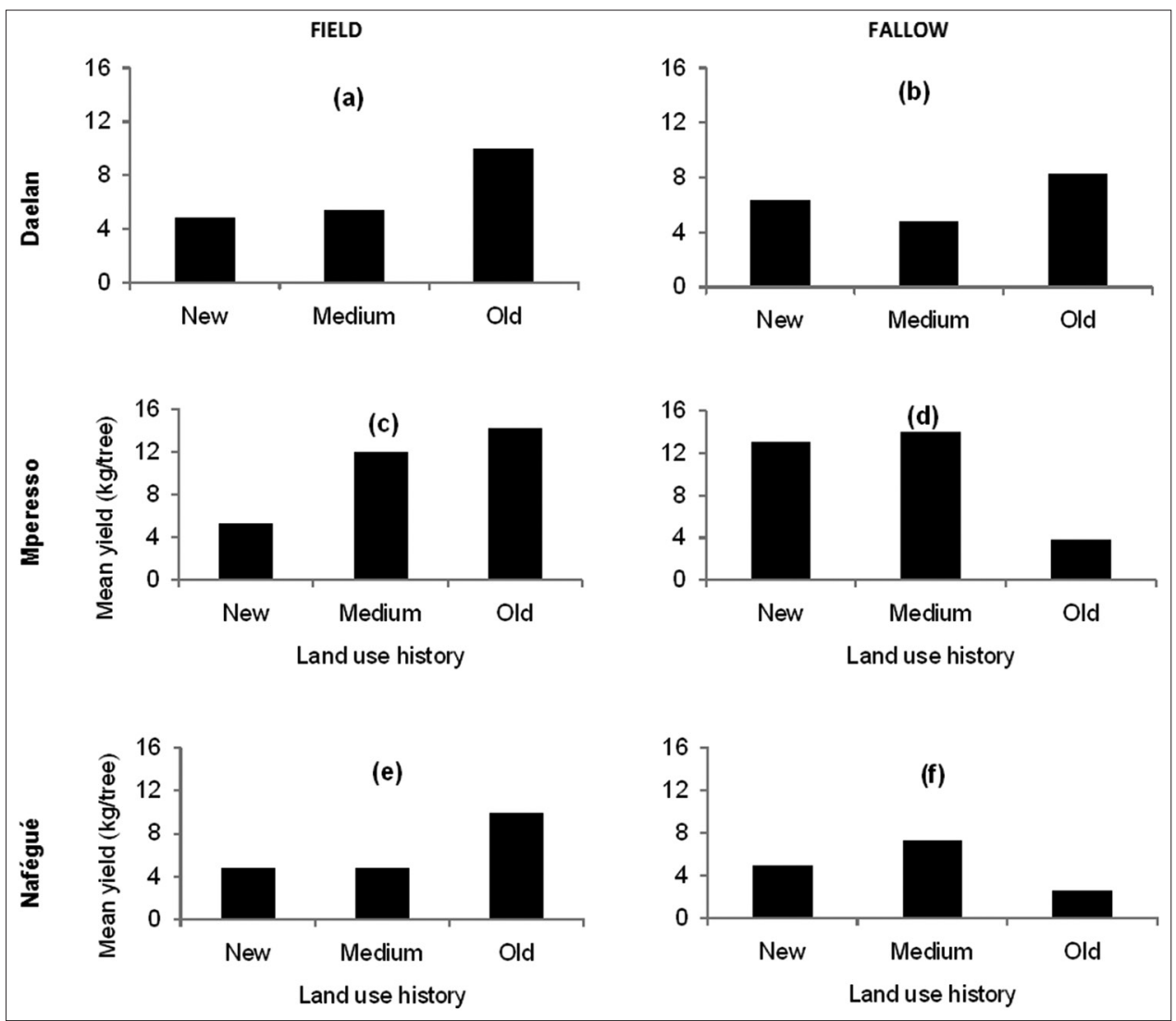

Figure 2: Fruit mean yield ( $\mathrm{kg} / \mathrm{tree})$ by land management within stand at each site

Table 3: Fruit mean yield by year according to land management within stand in each site

\begin{tabular}{|c|c|c|c|c|c|}
\hline \multirow[t]{2}{*}{ Site } & \multirow[t]{2}{*}{ Stand } & \multirow[t]{2}{*}{ Land management } & \multicolumn{3}{|c|}{$\begin{array}{l}\text { Mean fruit yield } \\
(\mathrm{kg} / \mathrm{tree}) \text { by year }\end{array}$} \\
\hline & & & 2008 & 2009* & 2010 \\
\hline Nafégué (North & Field & New ( $1-5$ years) & 6.6 & 3.2 & 4.6 \\
\hline \multirow[t]{7}{*}{ Guinean Zone) } & & Medium (6-10 years) & 6.5 & 4.6 & 3.2 \\
\hline & & Old (> years) & 17 & 6.9 & 5.4 \\
\hline & \multicolumn{2}{|c|}{ Field stand (all ages) } & 10 & 4.8 & 4.4 \\
\hline & \multirow[t]{4}{*}{ Fallow } & New ( $1-5$ years) & 8.1 & 2.7 & 3.7 \\
\hline & & Medium (6-10 years) & 6.1 & 7.7 & 7.8 \\
\hline & & Old (> years) & 2.6 & 2.2 & 2.9 \\
\hline & \multirow{2}{*}{\multicolumn{2}{|c|}{ Fallow stand (all ages) }} & 5.6 & 4.3 & 4.8 \\
\hline Nafégué (all stands) & & & 7.8 & 4.6 & 4.6 \\
\hline Mperesso (South & \multirow[t]{3}{*}{ Field } & New ( $1-5$ years) & 8.8 & 1.5 & 5.2 \\
\hline \multirow[t]{7}{*}{ Sudanian Zone) } & & Medium (6-10 years) & 19.8 & 2.2 & 9.1 \\
\hline & & Old (> years) & 29.8 & 2.1 & 6.3 \\
\hline & \multicolumn{2}{|c|}{ Field stand (all ages) } & 19.9 & 1.8 & 6.7 \\
\hline & \multirow[t]{4}{*}{ Fallow } & New (1-5 years) & 25.1 & 2 & 5.1 \\
\hline & & Medium (6-10 years) & 22.7 & 1.2 & 9.3 \\
\hline & & Old (> years) & 3.8 & - & 4 \\
\hline & \multirow{2}{*}{\multicolumn{2}{|c|}{ Fallow stand (all ages) }} & 17.2 & 1.5 & 6.4 \\
\hline Mperesso (all stands) & & & 18.5 & 1.7 & 6.6 \\
\hline Daelan (North & \multirow[t]{3}{*}{ Field } & New ( $1-5$ years) & 7.8 & & 7.3 \\
\hline \multirow[t]{7}{*}{ Sudanian Zone) } & & Medium (6-10 years) & 7.5 & & 4.1 \\
\hline & & Old (> years) & 12.4 & & 9.6 \\
\hline & \multicolumn{2}{|c|}{ Field stand (all ages) } & 9.2 & & 4.1 \\
\hline & \multirow[t]{4}{*}{ Fallow } & New (1-5 years) & 5.4 & & 1.4 \\
\hline & & Medium (6-10 years) & 5.3 & & 3.3 \\
\hline & & Old (> years) & 6.9 & & 7.4 \\
\hline & & ind (all ages) & 5.9 & & 7.1 \\
\hline Daelan (all stands) & & & 7.6 & & 5.6 \\
\hline
\end{tabular}

* Yield assessment was not done at Daelan in year 2009 because of very bad fruiting 
than the other two sites (Daelan in North Sudanian zone and Nafégué in North Guinean zone). Kelly et al. [15] observed similar pattern of difference between study sites regarding fruit production. Site effect was observed by authors on other aspects of Shea tree like the onset of phenological events [17], the variation of leaf and fruit morphological traits [24-26].

The pattern of the difference between sites suggests that fruit production of shea tree is not only explained by climatic conditions (rainfall quantity) since we observed that, the highest yielding site was not the rainiest site. Edaphic and anthropic factors seem to be determinant and could interact with other endogenous forces in fruit production of shea tree as highlithed by several authors $[18,15,16]$. The processes and levels of the interaction between these forces underlying the production of a given tree in a given site at a given time period were still not well understood.

\section{Stand (nested within Site) effect on fruit production of V. paradoxa}

The anova showed that the effect of stand was not significant when this factor is nested within the factor site. This result suggests that the general thinking of positive cultivation effect on shea fruit production [27, 28, 15]; hold only when stand is studied alone, i.e. without reference to site. This result suggests also that the effect of stand on fruit production of V. paradoxa could be hidden by site conditions. Cases of non-significant stand effect were reported by authors. For instance, Serpantié [29] reported that in Burkina Faso, yield of Vitellaria trees in fields and in fallows less than ten years old, located in deep fertile soils did not differ significantly. According to this author, "as well as the fallow is not ten years old and not covered by perennial grasses, it produces like the field" [30].

Studies assessing the impact of the land use (stand) on fruit production of shea tree are scarce. The few undertaken studies seem to minimise the impact of fallowing on fruit production, unless the fallow period become very long so that the stand fall in to the domain of natural forest stand. In the Bassila area of Benin, medium-sized trees $(28-37 \mathrm{~cm}$ in $\mathrm{dbh})$ in fields produced significantly higher yield than those in the bush [31]. Lamien et al. [27] reported that kernel average yield of shea trees located in agroforestry parklands in Burkina Faso was statistically higher than that of trees located in natural forests.

\section{Land management (nested within stand at each site) effect on fruit production of $\mathrm{V}$. paradoxa}

The anaova showed that the effect of land management within stand was significant. The pattern of the difference between management categories varies according to stands in the different sites. However, the general trend indicated that old fields (i.e. long cultivation activities) were better in terms of $\mathrm{V}$. paradoxa fruit production whereas old fallows were worst.

These findings are strengthening previous ones regarding this tree species. Pélissier [32] reported that the expansion of V. paradoxa is linked to human activities. Byakagaba et al. [33] studied shea fruit yield under different environmental conditions in Uganda and found that young fallows had better fruit yield compare to old fallows and current fields. Kelly et al. [15] also noticed the positive effect of cultivation practices on the flowering and fruiting of shea trees in parklands in southern Mali. Serpantié [30] noticed that a long fallow period ( $>10$ years) was negative for $\mathrm{V}$. paradoxa fruit production. Other authors reported that young fallows were better than old ones regarding flowering and fruiting of shea trees in southern Mali [15] and in Uganda [33].

Independently to sudied factors, fruit production of $\mathrm{V}$. paradoxa displayed significant variation according to years. For a time period of three years of monitoring, one year was found to be a very bad fruiting year particularly at the northern site (Daelan). Many previous studies have outlined this trait of shea tree. A cyclic production of the species ( 2 to 3 years, even more) has been reported by several authors $[34,19,15,16]$ even though the underlying factors are not yet well understood. Soro et al. [16] stated that the years of good production would occur every 5 years.

Boffa et al. [20] also found an important variation of nut production and estimated the average nut production in 1994 (1004 nuts) and 1995 (1047 nuts) almost five times of that observed in 1993 (219 nuts). In an attempt to explain this variation they concluded, “... the variable potential productivity of individual trees may be under the influence of external factors, which need to be identified". Soro et al. [16] think that entomophilous factor in the pollination plays a significant role in the variation of the production according to years. For Laroussilhe [35], the irregularity of fruit production could come from endogenous factor of regulation (e.g. one period of rest following a high production) or exogenic factors. Farmers however are really convinced that shea production within a given site is linked to the rainfall and that fruit production in a given year depends on the rainfall amount of the preceding year [36]

\section{CONCLUSION}

Findings of this study are important and could contribute to improve knowlege on fruit production of $\mathrm{V}$. paradoxa. Factors like site and land management appear to be determinant for fruit production of this species. Different pattern was observed between field and fallow stands regarding the effect of land management. More fields are aged, more they influence positively fruit production whereas more fallows are aged, and more they influence negatively fruit production. The study showed also even if land use type (stand) has an impact on fruit production of shea tree as noticed by several authors, the effect of this factor could be hidden or confounded with site effect when stand is nested within site.

An important variation of fruit production of shea tree according year was observed. This result strengthened findings of previous studies from which authors stated that "fruit production of shea tree is driven by several interacting biotic and abiotic forces". Discriminating the impact of these forces is not easy and need still to be investigated throughout shea distribution area. The time necessary for appropriate monitoring and deep investigation should be observed so that to help understanding how encountered factors are influencing fruit production of shea trees. This study highlighted the important effect of land management practices. Therefore, any domestication program 
should take into account this finding and adopt appropriate management practices.

\section{ACKNOWLEDGEMENTS}

We are very grateful to the European Union for funding the INNOVKAR project. Many thanks to field technicians Sabéré Coulibaly, Sékou Coulibaly, Idrissa Poudiougou and Ousmane Sanogo who worked hard in collecting phenological data and to all other colleagues at the Forestry Resources Programme. Many thanks also to Daelan, Mperesso and Nafégué village authorities and populations for allowing us to conduct this study on their land and parcels and for cooperating in field activities.

\section{REFERENCES}

1. Teklehaimanot Z. A field manual for propagation of Vitellaria paradoxa (karité). School of Agricultural and Forest Sciences. University of Wales, Bangor, UK, 18p; 2003.

2. Wiesman Z, Maranz S, Bianchi G and Bisgaard J. Chemical analysis of fruits of Vitellaria paradoxa. In: Improved management of agroforestry parkland systems in Sub-Saharan Africa, EU/INCO Project Contract IC18-CT98-0261, Final Report, University of Wales Bangor, UK, pp 133-141; 2003.

3. Maranz S, Wiesman Z, Bisgaard J, Bianchi G. Germplasm resources of Vitellaria paradoxa based on variations in fat composition across the species distribution range. Agroforestry Systems. 2004; 60: 71-76.

4. Davrieux F, Allal F, Piombo G, Kelly B, Okullo JB, Thiam M, Diallo OB, and Bouvet J-M. Near Infrared Spectroscopy for High-Throughput Characterization of Shea Tree (Vitellaria paradoxa) Nut Fat Profiles. Journal of Agricultural and Food Chemistry. 2010; 58: 7811-7819.

5. Otaiku A. Business Plan - Shea butter Production Small holder -to- Small Business. USAID/NEXTT. 30p+appendixes; 2016.

6. Koloche IM, Hamza AM, Mohammed A, Yahaya SA, Garba HM and Oladipo OF. The Quantity of Shea Nut Assessed, Collected and Processed Using Improved Shea Nut Processing Technologies in Niger State, Nigeria. American Journal of Experimental Agriculture. 2016; 12(2): 1-10

7. Market Research Future. Worldwide Shea Butter Market Size, Share, Statistics, Trend, Business Strategy, Top Key Players, Segmentation Analysis and Forecast to 2023. Market Research Future Office No. 528, Amanora Chambers Magarpatta Road, Hadapsar, Pune, State of Maharashtra, India. Website: https://www.marketresearchfuture. com/upcoming-reports/shea-butter-market-6160. 2018.

8. Collinson C and Zewdie-Bosuener A. Shea butter markets: Their implications for Ghanaian shea butter processors and exporters. Project A0772. 1999. Report No. 2403, 20 pp.

9. Lericollais A. La mort des arbres à Sob, en pays Sereer (Sénégal). In: Tropiques, lieux et Liens. Editions ORSTOM. 1999; 187-197.

10. Gijsbers HJM, Kessler JJ, and Knevel MK. Dynamics and natural regeneration of woody species in farmed parklands in the Sahel region (Province of Passoré, Burkina Faso). Forest Ecology and Management. 1994; 64:1-12.

11. Nikiema A, van der Maesen LJG and Hall JB. The impact of parkland management practices on plant resources diversity. In: Improved management of agroforestry parkland systems in Sub-Saharan Africa, EU/INCO Project Contract IC18-CT98-0261, Final report, University of Wales Bangor, UK. 2003; 43-50.

12. Maïga AY. Action thématique sur la mortalité du karité Butyrospermum paradoxum (Gaertner f) Hepper dans la région de Ségou - phase de prolongation: actualisation des chiffres de densité de karité au Mali. Rapport final de prolongation DRFH/INRZFH Sotuba, Mali. 1988; 48 pp.

13. Boussim J, Odebiyi A, Kambou S and Salle G. The ecology and biology of parasites and pests of parkland trees and their control methods. In: Improved management of agroforestry parkland systems in Sub-Saharan Africa, EU/INCO Project Contract IC18-CT98-0261, Final report, University of Wales Bangor, UK. 2003; 113-130.

14. Agbahungba $G$ et Depommier $D$. Aspects du parc à karités-nérés (Vitellaria paradoxa Gaertn. f. Parkia biglobosa Jacq. Benth.) dans le sud du Borgou (Bénin). Bois et Forêts des Tropiques. 1989; 222: 41-54.
15. Kelly BA, Gourlet-Fleury S, and Bouvet J-M. Impact of Agroforestry Practices on the Flowering Phenology of Vitellaria paradoxa in parklands in Southern Mali. Agroforestry Systems. 2007; 71: 67-75.

16. Soro D, N'Guessan Kand Soro K. Variability of production out of fruits of Shea trees. Agriculture and Biology Journal of North America. 2011; 2(2): 239-243

17. Kelly BA, Poudyal M, Bouvet J-M. Variation of Vitellaria paradoxa phenophases along the North-South Gradient in Mali. Research in Plant Biology. 2018;(8): 8-16.

18. Boffa J-M. Agroforestry parklands in sub-Saharan Africa. FAO, Rome. 1999; 230p.

19. Hall JB, Aebischer DP, Tomlinson HF, Osei-amaning E and Hindle JR Vitellaria paradoxa. A monograph. School of Agricultural and Forest Sciences Publication Number: 8, University of Wales, Bangor. 1996; $105 \mathrm{pp}$.

20. Boffa J-M, Yaméogo G, Nikiéma P and Knudson DM. Shea nut (Vitellaria paradoxa) production and collection in agroforestry parklands of Burkina Faso. International Conference on Domestication and Commercialisation of Non-Timber Production in Agroforestry Systems. 1996. Naïroby, Kenya. 19-23 February.

21. Goulart MF, Filho JPL, and Lovato MB. Phenological variation within and among Populations of Plathymenia reticulata in Brazilian Cerrado, the Atlantic Forest and Transitional Sites. Annals of Botany. 2005; 96:445-455.

22. Wiseman RE and Hopkins EA (eds). Sowing seeds of sustainability: Agriculture, Biodiversity, Economics and Society. UICN, Gland, Switzerland and Cambridge, U.K. 2001; 133 pp.

23. McDonald JH. Handbook of Biological Statistics (3rd ed.). Sparky House Publishing, Baltimore, Maryland. 2014.

24. Nyarko G, Mahunu GK, Chimsah FA, Yidana JA, Abubakari AH, Abagale FK, Quainoo A, Poudyal M Leaf and fruit characteristics of Shea (Vitellaria paradoxa) in Northern Ghana. Res. Plant Biol. 2012; 2(3):38-45.

25. Djekota C, Diouf D, Sane S, Mbaye MS, Noba K. Morphological characterization of Shea tree (Vitellaria paradoxa subsp. paradoxa) populations in the region of Mandoul in Chad. Int. J. Biodivers. Conserv. 2014; 6(2):184-193.

26. Kelly BA and Senou O. Variation of leaf and fruit characteristics of Vitellaria paradoxa (shea tree) according to agronomical performance along south-north climatic gradient in Mali. African Journal of Plant Science 2017; 11 (5):142 - 150

27. Lamien N, Ouédrago SJ, Diallo OB and Guinko S. Productivité fruitière du karité (Vitellaria paradoxa Gaertn. C.F., Sapotaceae) dans les parcs agroforestiers traditionnels au Burkina Faso. Fruits. 2004; 59: 423-429.

28. Okullo JBL, Hall JB and Obua J. Leafing, flowering and fruiting of Vitellaria paradoxa subsp. nilotica in savannah parklands in Uganda. Agroforestry Systems 2004; 60: 77-91.

29. Serpantié G. La production de karité (Butyrospermum paradoxum Gaertn.f. Hepper) des parcs arbores de l'Ouest Burkina Faso. Effets de différents modes de gestion. In C. Floret, ed. La jachère, lieu de production. 1997a; p. 73-80. Bobo Dioulasso, Burkina Faso, 2-3 Octobre 1996, CORAF-Union Européenne.

30. Serpantié G. Rôles des jachères dans la production arborée non ligneuse en savane soudanienne. Cas du Karité dans l'Ouest du Burkina Faso. In C. Floret, ed. La jachère, lieu de production. 1997b; p. 55-57. Bobo Dioulasso, Burkina Faso, 2-3 Octobre 1996, CORAFUnion Européenne.

31. Schreckenberg K. Forestn fields and markets: A study of indigenous tree products in the woody savannas of the Bassila region, Benin. Ph.D. Thesis. London, University of London. 1996; 326 pp.

32. Pélissier P. L'arbre dans les paysages agraires de l'Afrique noire. Cahiers ORSTOM, série Sciences Humaines. 1980; 17(3 et 4): 131-136.

33. Byakagaba P. Fruit yield under different environmental conditions in Uganda. Communication for the International Conference of the Project INNOVKAR. 2011. Ouagadou 24 - 26 october, Ougadougou, Burkina Faso.

34. Ruyssen B. Le Karité au soudan. Agronomie Tropicale. 1957; 12: 143-289.

35. Laroussilhe F. Le manguier, Techniques agricoles et productions tropicales G.P. Maisonneuve et Larose 15, Rue Victor-Cousin, 15 Paris Ve; 312. 1979.

36. Kelly BA, Yossi $\mathrm{H}$ et Senou O. Enrichissement des parcs à karité (Vitellaria paradoxa Gaertn.F.) en zone soudanienne au Mali: Identification et caractérisation agromorphologique des karités performants. 2011. Rapport d'Etude, Convention IER-CRRA Sikasso - Programme d'Appui aux Filières Agricoles (PAFA). 